\title{
Tree-ring growth patterns and temperature reconstruction from Nothofagus pumilio (Fagaceae) forests at the upper tree line of southern Chilean Patagonia
}

\author{
Patrones de crecimiento arbóreo y reconstrucción de la temperatura en bosques de \\ Nothofagus pumilio (Fagaceae) en el límite arbóreo superior de la \\ Patagonia austral de Chile
}

JUAN C. ARAVENA ${ }^{1}$, ANTONIO LARA ${ }^{2}$, ALEXIA WOLODARSKY-FRANKE ${ }^{2}$, RICARDO VILLALBA ${ }^{3} \&$ EMILIO CUQ $^{2}$

\author{
${ }^{1}$ Departamento de Biología, Facultad de Ciencias, Universidad de Chile, \\ Casilla 653, Santiago, Chile; e-mail: dendro@uchile.cl \\ ${ }^{2}$ Laboratorio de Dendrocronología, Instituto de Silvicultura, Universidad Austral de Chile, \\ Valdivia, Chile \\ ${ }^{3}$ Laboratorio de Dendrocronología, Centro Regional de Investigación en Ciencia y Tecnología, \\ Mendoza, Argentina
}

\begin{abstract}
Nothofagus pumilio (Poepp. et Endl. Krasser) is a deciduous species that dominates the upper tree line of the Chilean

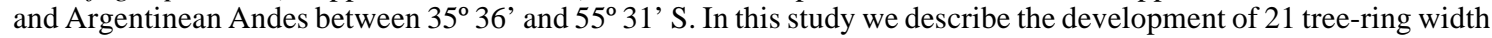
chronologies of $N$. pumilio across its southernmost range of distribution $\left(51-55^{\circ} \mathrm{S}\right)$ in Chile, and analyze the relationship between $N$. pumilio tree-growth and climate. Ten of the tree-ring chronologies in our study, show an increasing trend and/or above average tree-ring growth since ca. 1960 to 1996, which coincides with the increase in temperatures shown by instrumental records from southern Patagonia. Another dominant pattern in tree-growth is a remarkable ca. 7-year cycle present in three of the study sites from Isla Navarino, the southernmost of our study areas (ca. $55^{\circ} \mathrm{S}$ ). These two dominant tree-growth patterns, represent the main modes of variation of the $N$. pumilio tree-ring records in the southern Chilean Patagonia, accounting for 14 and $28 \%$ of its total variance, respectively. Based on the positive correlation between tree growth and temperature in several of the study sites analyzed in this work, we developed a reconstruction of the Punta Arenas minimum annual temperatures from the seven tree-ring records with the highest correlation with temperature, covering the $1829-1996$ period. The reconstruction shows that during most of the $19^{\text {th }}$ century, minimum annual temperatures remained below-average and increased to values fluctuating around the mean during the 19001960 period, followed by a clear trend with above-average values after 1963.
\end{abstract}

Key words: dendroclimatology, Nothofagus, tree-rings, tree line, Patagonia, warming trend.

\section{RESUMEN}

Nothofagus pumilio (Poepp. et Endl. Krasser) es una especie caducifolia que domina el límite arbóreo superior de los

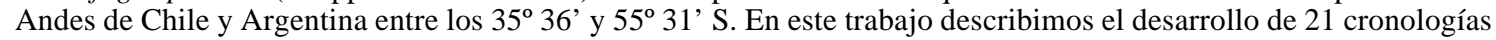
de ancho de anillos de $N$. pumilio para su rango más austral de distribución (51-55 $\mathrm{S})$ en Chile, así como el análisis de su relación con el clima. Diez de las cronologías de ancho de anillos estudiadas muestran una tendencia al incremento y/o crecimiento sobre el promedio a partir de aproximadamente 1960 hasta 1996, lo cual coincide con un incremento sostenido en las temperaturas mostrado por los registros instrumentales de la Patagonia austral. Otra característica particular del crecimiento de los árboles es un notable ciclo de cerca de 7 años presente en tres de los sitios de estudio en la Isla Navarino, el área de estudio más austral estudiada por nosotros $\left(55^{\circ} \mathrm{S}\right)$. Estos dos patrones de crecimiento, representan los principales modos de variación de los registros de anillos de crecimiento de N. pumilio en la Patagonia austral de Chile, y explican respectivamente el 14 y $28 \%$ de la varianza total. Sobre la base de la correlación positiva que se verifica entre el crecimiento arbóreo y la temperatura en varios de los sitios de estudio analizados en este trabajo, reconstruimos las variaciones de las temperaturas mínimas anuales de Punta Arenas para el período 1829-1996. La reconstrucción muestra que durante la mayor parte del siglo 19 las temperaturas mínimas anuales permanecieron por debajo del promedio, aumentando a valores que fluctuaron en torno a la media durante el período 1900-1960, seguido por una clara tendencia sobre la media para el período posterior a 1963.

Palabras clave: dendroclimatología, Nothofagus, anillos de crecimiento, límite arbóreo, Patagonia, tendencia al calentamiento. 


\section{INTRODUCTION}

The vast geographic distribution of Nothofagus pumilio (lenga) in southern South America $\left(35^{\circ}\right.$ $36^{\prime}$ to $55^{\circ} 31^{\prime} \mathrm{S}$ ), implies a broad ecological amplitude or tolerance range, as it is distributed along a north-south temperature and precipitation gradient, with important differences in the seasonality of the climate regimes (Donoso 1993, Veblen et al. 1996). This species is adapted to unstable environments, with a high frequency of catastrophic disturbances such as snow avalanches, tephra depositions, landslides and windstorms.

Nothofagus pumilio tree-ring chronologies have already been developed for northern Patagonia as well as Tierra del Fuego in Argentina (Boninsegna et al. 1989, Roig et al. 1996, Villalba et al. 1997, Schmelter 2000), and central Andes in Chile (Lara et al. 2001). These studies have demonstrated the relationship between spring-summer climate and Nothofagus pumilio tree-growth. Mean annual temperature and snow cover duration in northern Patagonia (Villalba et al. 1997), and summer temperatures in Tierra del Fuego (Boninsegna et al. 1989) have been reconstructed since 1750 . The latter temperature reconstruction from $N$. pumilio tree rings shows a clear increasing trend during the second half of the 20th century which coincides with the warming trend shown by the instrumental climatic records for southern Patagonia during the same period. In central Chile (Lara et al. 2001), tree-ring growth of $N$. pumilio is positively correlated with late-spring and earlysummer precipitation and higher temperatures reduce tree-growth.

Rosenblüth et al. (1997) demonstrate that most of the instrumental temperature records, in Chile and Argentina, show a general warming trend during the last decades. These authors show that the warming trend in the extreme south of South America $\left(45-55^{\circ} \mathrm{S}\right)$ is very consistent, and coincides with the results of other studies done in the Antarctic Peninsula (King 1994).

In this paper we describe the development of 21 tree-ring width chronologies of $N$. pumilio across

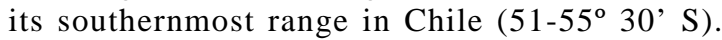
We analyze the growth trends of these $N$. pumilio forests, their relationships with the fluctuations of climatic variables and other probable forcing environmental factors. We also present a regional climate reconstruction from these chronologies which adds to the existing reconstructions from Chile and Argentina.

We expect that tree-growth of $N$. pumilio forests at tree-line in southern Chilean Patagonia will have a positive correlation with temperature.
At the drier sites towards the Patagonic steppe, we expect that tree-growth will be mainly related to precipitation (positive correlation). In addition, we expect an increasing trend in tree-growth of $N$. pumilio tree line forests during the last decades in the southern Chilean Patagonia as a response to increasing temperatures in this region described by Rosenblüth et al. (1997).

\section{Study area}

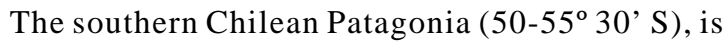
located in the extreme south of Chile in South America (Fig. 1). Its physiography varies from the western margin formed by an archipelago of mountainous islands, fiords and channels, to Andean massifs, with peaks reaching up to 2,500 $\mathrm{m}$, containing the Southern Icefields and many glaciers. The rivers which originate from these glaciers run on both sides of the Andean range, reaching a relatively low and flat area covered by fluvioglacial deposits towards the east, continuing through Argentina and reaching the Atlantic (Pisano 1977, Veblen et al. 1983).

\section{Climate}

The climate of this region is dominated by a dominant precipitation and humidity gradient, from the west decreasing towards the east. Towards the southern portion of this region, this gradient shifts from south-west to north-east, following the position of the Andean range, and the physiography of southern South America (Fig 1). The distribution of $N$. pumilio forests with the peatbogs and $N$. betuloides forests towards the western archipelagos and the Patagonic steppe towards the east, all the way to the Atlantic coast, reflects the position of this gradient and its shift towards the south. Precipitation is originated mainly by the influence of the westerly winds, which dominate the whole region. The Andean range intercepts these winds, which then rise leading to an annual rainfall of up to $8,000 \mathrm{~mm}$ on the windward side. The winds then reach the leeward side, creating drier conditions with an annual precipitation of $250 \mathrm{~mm}$ and less (Rosenblüth et al. 1997, Carrasco et al. 1998). There is almost no seasonality in the distribution of rainfall, especially on the windward western slopes of the Andes. In the leeward eastern slopes of the Andes, precipitation tends to be slightly higher in autumn and winter (Carrasco et al. 1998). There is a strong oceanic influence on temperature on the windward area of the Andes, with little 


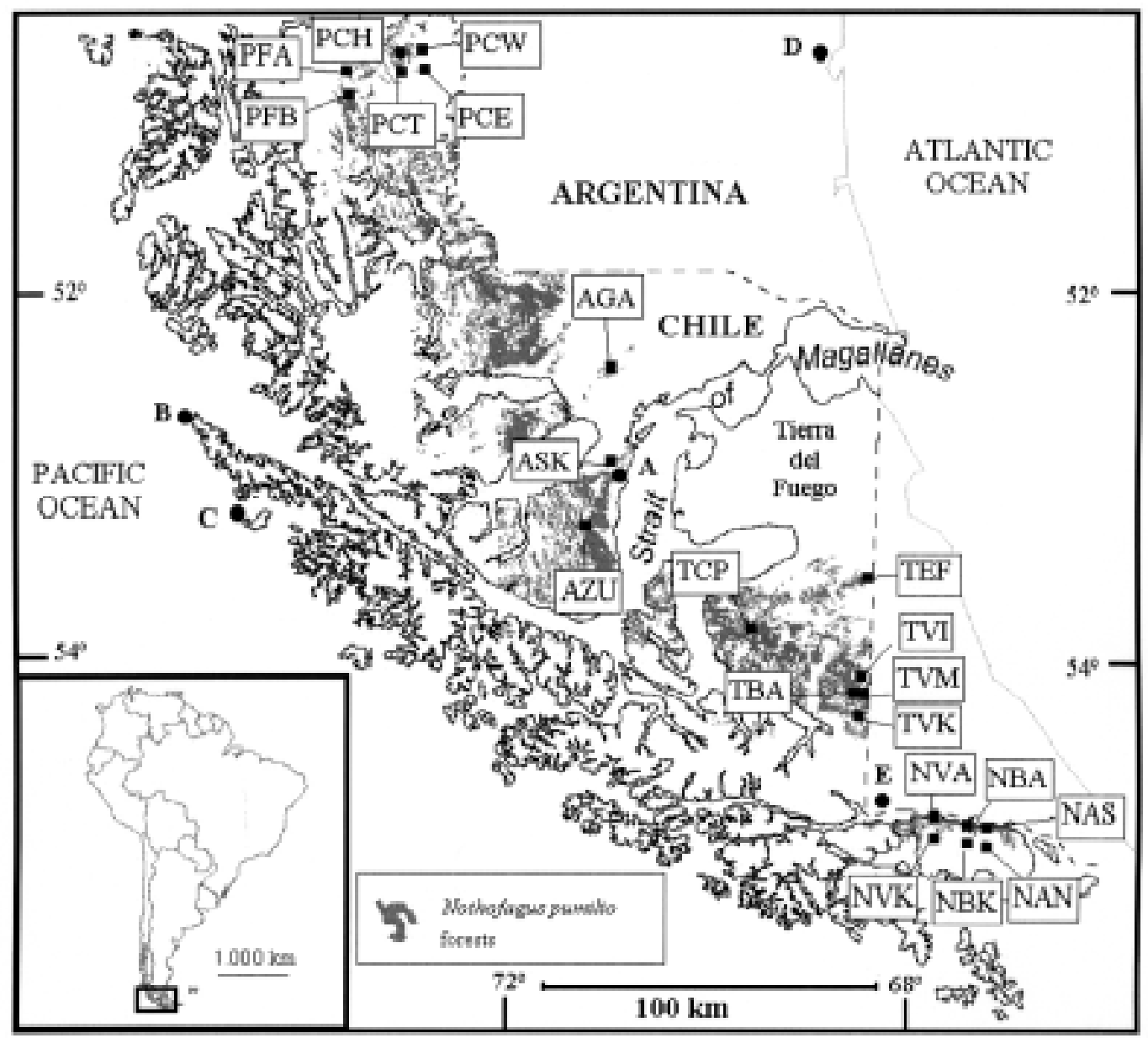

Fig. 1: Map of the study area, showing the location of the study sites identified by three-letter codes and the climatic stations (A through E). Names for the study sites and the climatic stations are given in Tables 1 and 2, respectively. Distribution of $N$. pumilio forests are shown in grey, limiting with the peatbogs and $N$. betuloides forests towards the western archipelagos and the Patagonic steppe towards the east, all the way to the Atlantic coast.

Mapa del área de estudio, indicando la ubicación de los sitios de estudio, identificados por códigos de tres letras y las estaciones meteorológicas (A-E). Los nombres de los sitios de estudio y de las estaciones meteorológicas se dan en las Tablas 1 y 2 , respectivamente. La distribución de los bosques de $N$. pumilio se muestra en gris, limitando hacia el oeste con las turberas y los bosques de $N$. betuloides y hacia el este con la estepa patagónica que se desarrolla hasta alcanzar la costa Atlántica.

seasonal variation in mean monthly temperature. For example, in Faro Evangelistas, located at $52^{\circ}$ $24^{\prime} \mathrm{S}, 75^{\circ} 06^{\prime} \mathrm{W}$ in the western archipelagos, the mean temperature for January is about $8^{\circ} \mathrm{C}$ and of $4{ }^{\circ} \mathrm{C}$ for July. Conversely, in Punta Arenas which is located leeward $\left(53^{\circ} 00^{\prime} \mathrm{S}, 70^{\circ} 51^{\prime} \mathrm{W}\right)$, values range from $10^{\circ} \mathrm{C}$ in January to $1{ }^{\circ} \mathrm{C}$ or less in July (Rosenblüth et al. 1997).

\section{Vegetation}

Vegetation distribution in the southern Chilean Patagonia is highly determined by the precipita- tion and humidity gradients, defining the main vegetation zones. At the windy western margin, with extensive areas of poor drainage vegetation is dominated by peatbogs and heaths. In this area, forests are often dwarf (2-8 m tall) and normally grow in creeks and sheltered areas, dominated by the evergreen Nothofagus betuloides, Pilgerodendron uviferum, and Tepualia stipularis. Towards the east, the low islands and mountain slopes with better drained soils are covered by taller $N$. betuloides forests (8-20 m tall). Further inland and following the decreasing precipitation gradient, deciduous forests of $N$. pumilio dominate the landscape growing as pure stands or 
mixed with $N$. betuloides. These forests grow from an altitude of ca. $100 \mathrm{~m}$ to tree line, which ranges from $900-980 \mathrm{~m}$ on the northernmost study sites at Torres del Paine to 550-625 $\mathrm{m}$ in the southernmost sites in Isla Navarino. N. pumilio grows up to $20-25 \mathrm{~m}$ tall in the lower elevation, more mesic sites, with short, erect, 4-10 m tall trees, or as 1-4 m tall krummholz, at high elevation or tree line sites, depending on aspect, windiness, snow accumulation and other characteristics. High-elevation $N$. pumilio stands are normally dense and form a continuous tree line, different to other patchy tree lines which have been described for other areas in the Northern Hemisphere (Donoso 1981, Veblen \& Schlegel 1982, Payette \& Filion 1984, Veblen et al. 1996). Nothofagus antarctica grows as a short tree or forms krummholz belts around peatbogs, or grows at drier sites forming an ecotone with the Patagonic steppe towards the east, dominated by grasslands, shrublands and heaths. In some cases, $N$. antarctica forms krummholz at tree line (Godley 1960, Pisano 1977, Veblen et al. 1983).

The distribution of $N$. pumilio forests limiting with the peatbogs and evergreen forests towards the western archipelagos and the Patagonic steppe towards the east, responds to the precipitation gradient that shifts from a west to east orientation to a south-west to north-east orientation towards the south, following the physiography of the region (Fig. 1).

\section{Sampling sites}

We sampled trees along a north-south gradient from 21 sites in four main areas: Torres del Paine, Punta Arenas, Tierra del Fuego, and Isla Navarino (Table 1, Fig. 1). In Torres del Paine National Park, the six sampling sites were distributed along a west to east precipitation gradient. The wetter sites were located on the slopes of Mount Ferrier (PFA, PFB) towards the west, and near some $N$. betuloides forests. Two more sites were located in the massif of Torres del Paine (PCH, PCT), and the final two sites on Sierra Contreras (PCW, PCE) at the eastern dry extreme of the precipitation gradient.

In the Punta Arenas area, sampling included one humid site in Cerro Azul (AZU), south of the city of Punta Arenas, one intermediate site in the skiing area of Punta Arenas (ASK), and one site in the driest extreme of the gradient, north of Punta Arenas, in Monte Gallina (AGA), in the ecotone with the Patagonic steppe.

In Tierra del Fuego six sites were sampled along the precipitation gradient, from the more humid southwestern towards the drier northeast-

TABLE 1

Site characteristics of tree-ring chronologies

Características de los sitios de las cronologías de anillos de crecimiento

\begin{tabular}{|c|c|c|c|c|c|c|c|}
\hline Study area & & Sampling site & Site code & $\begin{array}{l}\text { Latitude } \\
\text { (S) }\end{array}$ & $\begin{array}{l}\text { Longitude } \\
\text { (W) }\end{array}$ & $\begin{array}{l}\text { Elevation } \\
\quad(\mathrm{m})\end{array}$ & Aspect \\
\hline \multirow[t]{6}{*}{ Torres del Paine } & 1 & Cerro Ferrier A & PFA & $51^{\circ} 09^{\prime}$ & $73^{\circ} 18^{\prime}$ & 650 & $\mathrm{NE}$ \\
\hline & 2 & Cerro Ferrier B & PFB & $51^{\circ} 09^{\prime}$ & $73^{\circ} 17^{\prime}$ & 650 & $\mathrm{SE}$ \\
\hline & 3 & Campo Chileno & $\mathrm{PCH}$ & $50^{\circ} 57^{\prime}$ & $72^{\circ} 53^{\prime}$ & 675 & SW \\
\hline & 4 & Campo Torres & PCT & $50^{\circ} 57^{\prime}$ & $72^{\circ} 54^{\prime}$ & 980 & NNW \\
\hline & 5 & Contreras W & PCW & $50^{\circ} 48^{\prime}$ & $72^{\circ} 36^{\prime}$ & 920 & SW \\
\hline & 6 & Contreras E & PCE & $50^{\circ} 48^{\prime}$ & $72^{\circ} 30^{\prime}$ & 910 & $\mathrm{SE}$ \\
\hline \multirow[t]{3}{*}{ Punta Arenas } & 7 & Monte Azul & $\mathrm{AZU}$ & $53^{\circ} 22^{\prime}$ & $71^{\circ} 13^{\prime}$ & 500 & SW \\
\hline & 8 & Cancha de Ski & ASK & $53^{\circ} 09^{\prime}$ & $71^{\circ} 02^{\prime}$ & 600 & SE \\
\hline & 9 & Monte Gallina & AGA & $52^{\circ} 31^{\prime}$ & $71^{\circ} 01^{\prime}$ & 350 & $\mathrm{SE}$ \\
\hline \multirow[t]{6}{*}{ Tierra del Fuego } & 10 & Cerro Pascua & $\mathrm{TCP}$ & $53^{\circ} 55^{\prime}$ & $69^{\circ} 43^{\prime}$ & 500 & NW \\
\hline & 11 & Cerro Balseiro & TBA & $54^{\circ} 14^{\prime}$ & $68^{\circ} 40^{\prime}$ & 510 & SW \\
\hline & 12 & Campo XX Inferior & TVI & $54^{\circ} 16^{\prime}$ & $68^{\circ} 41^{\prime}$ & 250 & $\mathrm{~N}$ \\
\hline & 13 & Campo XX Medio & TVM & $54^{\circ} 17^{\prime}$ & $68^{\circ} 41^{\prime}$ & 450 & NW \\
\hline & 14 & Campo XX Krummholz & TVK & $54^{\circ} 17^{\prime}$ & $68^{\circ} 41^{\prime}$ & 600 & $\mathrm{NE}$ \\
\hline & 15 & Estancia Las Flores & TEF & $53^{\circ} 38^{\prime}$ & $68^{\circ} 42^{\prime}$ & 141 & $\mathrm{E}$ \\
\hline \multirow[t]{6}{*}{ Isla Navarino } & 16 & Cerro Vallerino Abajo & NVA & $54^{\circ} 54^{\prime}$ & $68^{\circ} 00^{\prime}$ & 300 & $\mathrm{~N}$ \\
\hline & 17 & Cerro Vallerino Krummholz & NVK & $54^{\circ} 54^{\prime}$ & $68^{\circ} 00^{\prime}$ & 530 & $\mathrm{~N}$ \\
\hline & 18 & Cerro Bandera Abajo & NBA & $54^{\circ} 56^{\prime}$ & $67^{\circ} 36^{\prime}$ & 450 & NW \\
\hline & 19 & Cerro Bandera Krummholz & NBK & $54^{\circ} 58^{\prime}$ & $67^{\circ} 37^{\prime}$ & 560 & NW \\
\hline & 20 & Aserradero $\mathrm{S}$ & NAS & $54^{\circ} 57^{\prime}$ & $67^{\circ} 31^{\prime}$ & 600 & $\mathrm{~S}$ \\
\hline & 21 & Aserradero NW & NAN & $54^{\circ} 57^{\prime}$ & $67^{\circ} 32^{\prime}$ & 536 & NW \\
\hline
\end{tabular}


ern areas. The first site was located in the humid extreme on Cerro Pascua (TCP), characterized by a tree line of stunted Nothofagus antarctica trees. Three sites were located in an intermediate area near Estancia Vicuña, on the north-facing slope of Campo El Veinte (TVK, TVM, TVI). The sampling site on Cerro Balseiro (TBA) was located close to the study site selected by Cuevas \& Arroyo (1999). Finally, trees were sampled in the drier extreme of the gradient in the ecotone with the Patagonic steppe at Estancia Las Flores (TEF).

In the area of Isla Navarino, the sampling sites were located across a west to east transect. In the western part of the island, two sites were located at different elevations on the north-facing slope of Cerro Vallerino (NVA and NVK). Two stands in the central part of the island were sampled at different elevations on Cerro Bandera (NBK and NBA). The last two collections are located towards the east, at the same elevation but different aspect, in the sector of Aserradero (NAS and NAN).

\section{MATERIAL AND METHODS}

\section{Chronology development}

Two cores were extracted from 15-40 trees at each sampling site, using increment borers. Cores were mounted, sanded using sandpaper of increasingly finer grit, and dated following the techniques outlined in Stokes \& Smiley (1968). Tree-ring widths were measured under a microscope to the nearest $0.001 \mathrm{~mm}$ and stored in a microcomputer (Robinson \& Evans 1980). The computer program COFECHA (Holmes 1983) was used to detect measurement and cross-dating errors. For dating purposes, we followed Schulman's convention (1956) for the Southern Hemisphere, which assigns to each tree ring the date of the year in which radial growth started.

Once the tree-ring series were dated, ring width data were standardized and averaged to produce a mean stand chronology for each site (Fritts 1976, Cook 1985). Standardization was performed using the program ARSTAN (Cook \& Holmes 1984, Cook 1985), which generates mean chronologies by averaging standardized tree-ring series with biweight robust estimation. Standardization involves fitting the observed ring-width series with a theoretical curve, and computing an index by subtracting the logarithms of the expected from the observed values. This reduces variance among cores, removes the tree's biological growth trend from ring-width series and avoids potential biases in the tree-ring indexing procedure (Fritts
1976, Cook et al. 1992). In order to preserve the low-frequency variations in the tree-ring series, we used a very conservative standardization method. Tree-ring series were standardized by fitting them to negative exponential curves, linear regressions of negative slope or horizontal lines as theoretical curves of standardization.

\section{Analysis of tree-ring growth patterns}

In order to evaluate the intercorrelation and spatial variability among the chronologies we performed a Principal Component Analysis (PCA) on the matrix of correlation formed by the 21 treering chronologies (Cooley \& Lohnes 1971). The 1897-1996 common interval was used to compare chronologies. Additionally, a frequency domain analysis was conducted on the same 21 tree-ring chronologies. We used a spectral (Fourier transformation) time series analysis that allowed us to examine the spectral density function for each chronology separately. This spectral analysis is concerned with the exploration of cyclical patterns in the tree-growth data. The purpose of the analysis is to decompose tree-ring time series with cyclical components into a few underlying sinusoidal (sine and cosine) functions of particular wavelengths (Jenkins \& Watts 1968).

\section{Climatic influences on radial growth}

For the identification of the influence of macroclimatic factors on Nothofagus pumilio radial growth, we computed correlation between standard chronologies (Cook 1985) and monthly mean temperature and total precipitation (Fritts 1976, Blasing et al. 1984). The climatic stations used in the analysis are described in Table 2. These climatic stations were selected among others because they presented the most complete, longest and more consistent records for precipitation and temperature in southern Patagonia. We used the standard chronologies to preserve lowfrequency variance in radial growth, which is removed from the residual versions of the chronologies. The statistical association between ring indices and temperature and precipitation was examined over the common period for the chronology and the available instrumental climatic records (1930-1992). As radial tree growth is influenced by climatic conditions several months before ring formation (Fritts 1976), we included both the previous and current growing seasons in this analysis. Consequently, correlation between ring width and climate data was calculated for 17 
TABLE 2

Characteristics of the climatic stations used in this study; $\mathrm{T}=$ temperature $\left({ }^{\circ} \mathrm{C}\right) ; \mathrm{P}=$ precipitation

Características de las estaciones climáticas utilizadas en este estudio; $\mathrm{T}=$ temperatura $\left({ }^{\circ} \mathrm{C}\right) ; \mathrm{P}=$ precipitación

\begin{tabular}{|c|c|c|c|c|c|c|}
\hline \multicolumn{2}{|c|}{ Station } & \multirow{2}{*}{$\begin{array}{c}\text { Data period } \\
1905-1992\end{array}$} & \multirow{2}{*}{$\begin{array}{c}\begin{array}{c}\text { Latitude } \\
(\mathrm{S})\end{array} \\
53^{\circ} 00^{\prime}\end{array}$} & \multirow{2}{*}{$\begin{array}{c}\begin{array}{c}\text { Longitude } \\
\text { (W) }\end{array} \\
70^{\circ} 51^{\prime}\end{array}$} & \multirow{2}{*}{$\begin{array}{c}\begin{array}{c}\text { Elevation } \\
(\mathrm{m})\end{array} \\
37\end{array}$} & \multirow{2}{*}{$\begin{array}{c}\text { Variables } \\
\mathrm{T}, \mathrm{P}\end{array}$} \\
\hline A & Punta Arenas & & & & & \\
\hline B & Faro Evangelistas & 1900-1992 & $52^{\circ} 24^{\prime}$ & $75^{\circ} 06^{\prime}$ & 60 & $\mathrm{P}$ \\
\hline $\mathrm{C}$ & Bahía Félix & 1913-1986 & $53^{\circ} 01^{\prime}$ & $74^{\circ} 55^{\prime}$ & 40 & $\mathrm{P}$ \\
\hline D & Río Gallegos & 1931-1990 & $51^{\circ} 36^{\prime}$ & $68^{\circ} 18^{\prime}$ & 50 & $\mathrm{~T}$ \\
\hline E & Ushuaia & 1911-1986 & $54^{\circ} 40^{\prime}$ & $68^{\circ} 10^{\prime}$ & 40 & $\mathrm{~T}$ \\
\hline
\end{tabular}

months, starting in January of the previous growing season, and ending in May of the current growing season.

\section{Climate reconstruction}

In order to reconstruct past climate variations in the southern Chilean Patagonia, we correlated the chronologies with annual and seasonal variations of temperature and precipitation. Many possible combinations of both the tree-ring and climate data sets were used to explore the feasibility of reconstructing a variety of temperature and/or precipitation parameters. We used multiple regression on principal components of the ringwidth series (Cooley \& Lohnes 1971) to predict climate as a function of tree-ring growth variation. This procedure generated a transfer function equation or model, which was then applied to the tree-ring data to develop the reconstruction (Fritts 1976). To maximize the climatic signal in the tree-ring chronology, we only used mean site chronologies that were significantly $(\mathrm{P}<0.05)$ correlated with the 1930-1992 climatic records. As radial growth in any specific year is influenced by the climate in both the current $(t)$ and previous (t-1) years, we modeled climate as a function of radial growth in both years $t$ and $t-1$. The stability of the multiple regression was evaluated using a cross validation approach (Fritts 1976). Using this procedure, we split the climatic record into two sub-periods of 31 years each: 1931-1961, and 1962-1992. We used one of these sub-periods for calibration and the other one for verification, and vice versa. For each calibrationverification trial, we first obtained the transfer functions over the calibration period, and then we evaluated the goodness of fit over the verification period. Several possible combinations of the available climate data were used in calibration at- tempts. The results in this paper are the best ones we have obtained with the available climate data. We measured the quality of the two transfer functions using the Pearson correlation coefficient $(\mathrm{r})$, product mean test $(\mathrm{t})$, and reduction of error statistic (RE).

\section{RESULTS}

\section{Characteristics of the tree-ring chronologies}

The time interval covered by the chronologies ranges between 129 and 336 years, most of them being over 200 years long (Table 3 ). The number of trees and radii that were finally included in the chronologies varies from 15 to 42 , and from 20 to 72 , respectively.

Mean sensitivity and the standard deviation are measures of the total variability in a chronology, mean sensitivity characterizing the year-to-year variability in tree-ring records (Fritts 1976, 1991). The chronologies of southern Chilean Patagonia have a large variability in mean sensitivity and standard deviation values, ranging from 0.19 to 0.36 and from 0.22 to 0.42 , respectively. Sites TBA and NAN have the highest values of mean sensitivity ( 0.36 both, Table 3 ). Autocorrelation of order 1 varies widely between sites, ranging from 0.40 in both NBA and NVA to 0.83 in ASK, a site characterized by stunted trees (krummholz) in the Punta Arenas area (Table 3).

\section{Tree-growth patterns}

Several of the tree-ring chronologies of our study, show an increasing trend and/or above average tree-ring growth since ca. 1960 to 1996 (Fig. 2). In the Torres del Paine study area, tree-growth at PCE shows above-average values since 1960, and 

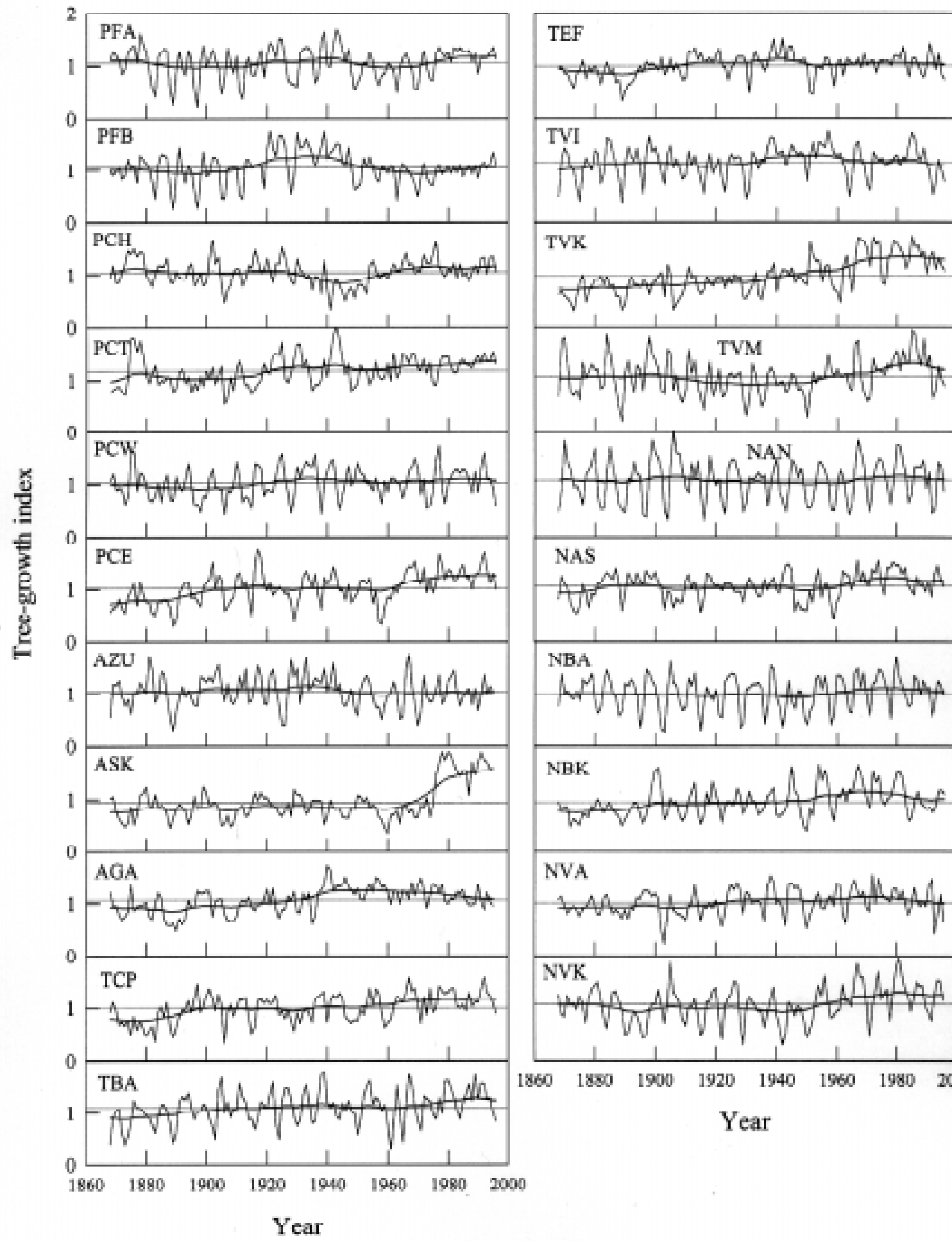

NAS APA

NBK

NVA

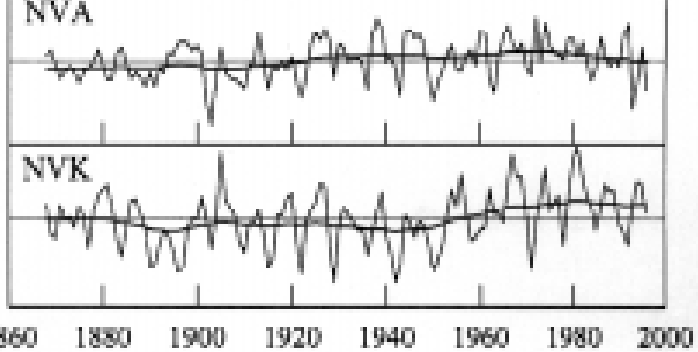

Year

Fig. 2: Tree-ring index variations for Nothofagus pumilio standard chronologies in Southern Chilean Patagonia. A trend line drawn for each curve to emphasize the low-frequency variation was obtained using an exponential filter (Rosenblüth et al. 1997). See Table 1 for the identification of the study sites. Variaciones de índices de anillos de crecimiento para cronologías estándar de Nothofagus pumilio en la Patagonia austral de Chile. La línea de tendencia para cada curva enfatiza la variación de baja frecuencia y se obtuvo usando un filtro exponencial (Rosenblüth et al. 1997). Ver Tabla 1 para la identificación de los sitios de estudio. 
to a lesser extent this pattern is also present in PCT. In the Punta Arenas study area, site ASK has an increasing trend since 1960 with a sharp increase in tree-growth since 1970. In the Tierra del Fuego study area, the increasing trend in tree growth since 1960 is more evident at higher elevation sites (TVK, TBA and TCP) and TVM shows mostly above-average growth in this period. These patterns are not apparent in the lower elevation sites (TVI and TEF).

Tree-ring chronologies NVK, NAS and NBK in the Isla Navarino area show above average growth values since 1960. However, the most evident pattern in the Isla Navarino chronologies is a marked cyclicity in tree growth in sites NAN, NBA and NVK, persistent through all the time period (Fig. 2). In order to better examine the cyclic pattern in the tree growth of our southern Patagonia chronologies, we applied a Fourier transformation to each tree-ring chronology (Fig. 3), analyzing the spectral density of these time series at the frequency domain. In the Isla Navarino study area the chronologies already mentioned (NAN, NBA and NVK), have growth variations with a strong cyclicity concentrated around 7 years (Fig. 3). This is particularly clear in the case of the study site NAN, where the values of spectral density are much higher compared to the values for the other sites. In addition, the cycles of ca. 7 years in $N$. pumilio growth observed at sites NAN, NBA and NVK are synchronous as indicated by the phase spectrum analysis (not shown).

The spatial pattern of cyclic tree growth is also shown by plotting the two first principal components of the 21 chronologies using the common interval 1897-1996 for the comparisons (Fig. 4). The principal component 1 (PC1), that explains $28 \%$ of the total variance, segregates those southernmost chronologies with a more consistent cyclic growth pattern (NAN, NBA and NVK) from the other chronologies, with PC 1 values $>0.5$. Chronologies NBK and NVA, located in the same study area, have also high values in PC 1 . On the other hand, tree-ring chronologies that have the highest values in the PC2 axis (PCT, PCE, ASK, TVK, TCP and NAS) are among those that present an above-average growth since ca.1960 (Fig. 2). Therefore, PC 2, accounting for $14 \%$ of the total variance, seems to be related to this growth pattern, which coincides with an increasing trend described for the regional temperature from instrumental records for the last decades (Rosenblüth et al. 1997). In fact, if we compare the regional annual temperature record with the amplitudes of PC 2, there is a high correlation coefficient $(r=0.48, P<0.0001)$.

TABLE 3

Descriptive statistics for the 21 Nothofagus pumilio standard chronologies from southern Patagonia

Estadísticas descriptivas para las 21 cronologías estándar de Nothofagus pumilio de la Patagonia austral

\begin{tabular}{lcccccccc}
\hline Study area & $\begin{array}{c}\text { Chronology } \\
\text { code }\end{array}$ & Interval & $\begin{array}{c}\text { Number } \\
\text { of years }\end{array}$ & $\begin{array}{c}\text { Number } \\
\text { of trees }\end{array}$ & $\begin{array}{c}\text { Number } \\
\text { of radii }\end{array}$ & $\begin{array}{c}\text { Mean } \\
\text { sensivity }\end{array}$ & $\begin{array}{c}\text { Standard } \\
\text { deviation }\end{array}$ & $\begin{array}{c}\text { Autocorrelation } \\
\text { order 1 }\end{array}$ \\
\hline Torres del Paine & PFA & $1730-1996$ & 267 & 28 & 49 & 0.28 & 0.32 & 0.55 \\
& PFB & $1685-1996$ & 312 & 29 & 51 & 0.26 & 0.29 & 0.52 \\
& PCH & $1816-1996$ & 181 & 15 & 25 & 0.21 & 0.27 & 0.59 \\
& PCT & $1774-1996$ & 223 & 20 & 29 & 0.26 & 0.33 & 0.69 \\
& PCW & $1793-1996$ & 204 & 38 & 62 & 0.28 & 0.29 & 0.42 \\
Punta Arenas & PCE & $1819-1996$ & 178 & 25 & 33 & 0.24 & 0.30 & 0.64 \\
& AZU & $1731-1996$ & 266 & 30 & 48 & 0.30 & 0.32 & 0.44 \\
Tierra del Fuego & ASK & $1829-1996$ & 168 & 42 & 49 & 0.20 & 0.36 & 0.83 \\
& AGA & $1773-1996$ & 224 & 39 & 72 & 0.21 & 0.24 & 0.58 \\
& TBA & $1661-1996$ & 336 & 40 & 67 & 0.36 & 0.35 & 0.44 \\
& TCP & $1800-1996$ & 197 & 34 & 52 & 0.29 & 0.42 & 0.61 \\
& TEF & $1793-1996$ & 204 & 31 & 56 & 0.19 & 0.22 & 0.45 \\
& TVK & $1805-1996$ & 192 & 26 & 41 & 0.24 & 0.31 & 0.64 \\
& TVM & $1784-1996$ & 213 & 21 & 26 & 0.32 & 0.34 & 0.46 \\
& TVI & $1808-1996$ & 189 & 25 & 33 & 0.31 & 0.35 & 0.67 \\
& NAN & $1741-1996$ & 256 & 20 & 30 & 0.36 & 0.38 & 0.47 \\
& NAS & $1811-1996$ & 186 & 39 & 63 & 0.25 & 0.29 & 0.57 \\
& NBA & $1790-1996$ & 207 & 25 & 36 & 0.31 & 0.31 & 0.40 \\
& NBK & $1868-1996$ & 129 & 16 & 20 & 0.21 & 0.29 & 0.63 \\
& NVA & $1762-1996$ & 235 & 33 & 55 & 0.25 & 0.25 & 0.40 \\
& NVK & $1830-1996$ & 167 & 26 & 39 & 0.28 & 0.34 & 0.62 \\
\hline
\end{tabular}


Tree-growth response to climatic variations

We studied tree-growth response to temperature and precipitation using correlation analyses. Figure 5 shows the spatial and temporal distribution of the correlation between the 21 tree-ring width chronologies and monthly temperature and precipitation regional averages calculated from the climatic stations listed in Table 2. Statistically significant correlation with temperature or precipitation are indicated as areas enclosed by the $95 \%$ of confidence isoline (in our case Pearson's

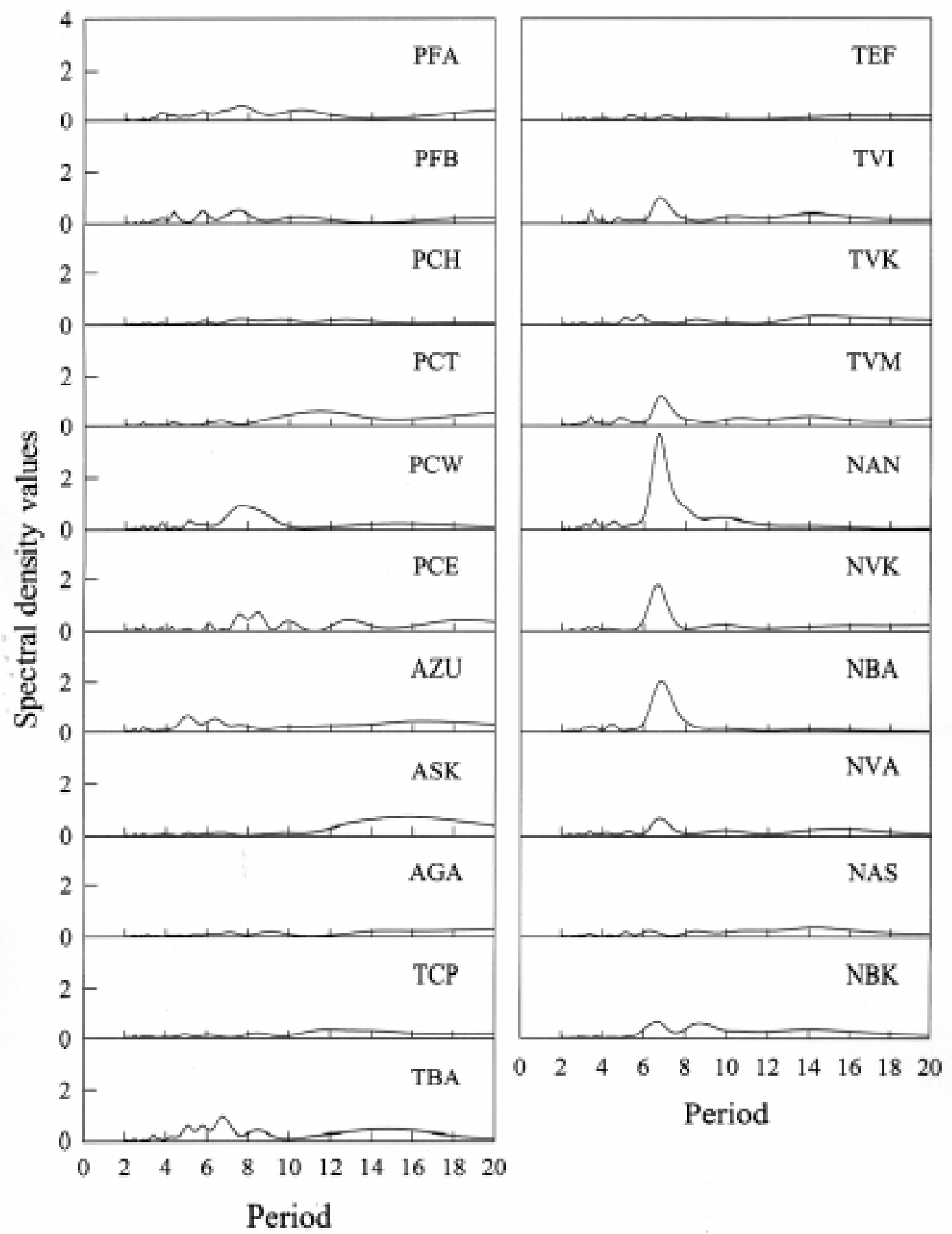

Fig. 3: Spectral density variations for Nothofagus pumilio chronologies in southern Chilean Patagonia. See Table 1 for the identification of the study sites.

Variaciones de la densidad espectral para cronologías de Nothofagus pumilio en la Patagonia austral de Chile. Ver Tabla 1 para la identificación de los sitios de estudio. 


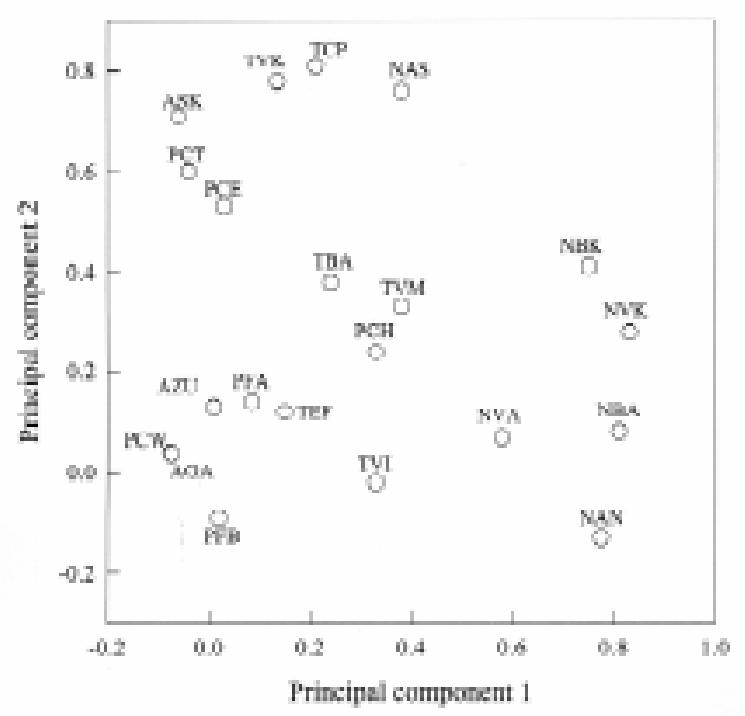

Fig. 4: Relative position of 21 standard chronologies from Nothofagus pumilio in southern Chilean Patagonia in relation to PC1 and PC2 from a rotated principal component analysis. See Table 1 for the identification of the study sites.

Posición relativa de las 21 cronologías estándar de Nothofagus pumilio en la Patagonia austral de Chile en relación a PC1 y PC2 del análisis de componentes principales rotados. Ver Tabla 1 para la identificación de los sitios de estudio.

correlation indexes $\geq \pm 0.21$ ). Tree-ring indices at many of the study sites are positively correlated with summer temperature months (December-January) of the current growing season in most sites (Fig. 5A). Additionally, there is also a significant positive correlation between tree growth and fall-early winter temperature of the previous growing season (April-June) at several study sites. The tree-ring chronologies that show this positive correlation with temperature are mostly the ones with a clear above-average growth since ca. 1960 with few exceptions (Fig. 2). These study sites (PCT, PCE, ASK, TVK, TCP, TBA and NAS) also show the highest values in the PC 2 axis obtained from the 21 tree-ring chronologies (Fig. 4). Therefore, they represent sites which are very sensitive to the warming trend observed in the climatic series of southern South America (Rosenblüth et al. 1997). Conversely, sites NAN and NBA that do not show a positive response to temperature, are the ones with the highest PC1 values, associated to a strong 7-year cycle in tree growth (Fig. 3 and 4). Site NVK is a special case, because it has a clear 7-year cycle and a high PC1 score (Fig. 3 and 4) but, contrary to sites NAN and NBA, it shows a positive response to temperature of several months of the current and the previous growing season (Fig. 5A). NVK is the site within the Isla Navarino area that shows the greatest increase in tree-growth since 1960 (Fig.2), so this tree-ring chronology presents both a climatic and a presumably non-climatic signal (7-year cycle).

Regarding tree ring response to regional precipitation average (Fig 5B), only a small number of chronologies show some significant correlation. Tree-ring chronologies ASK, TVK, TVM and TVI have a negative correlation with the late autumn precipitation of the previous growing season (April-May in most sites), while NVA and NVK show a negative correlation, with the MayJune precipitation of the previous growing season.

The response functions calculated from the regional averages of the weather stations shown in Table 2 provided similar results than the analysis done for individual stations (data not shown). Nevertheless, the correlation of the Punta Arenas instrumental record, and $N$. pumilio tree-growth show some special patterns (Fig. 6). Regarding temperature, Punta Arenas shows a positive correlation with the tree-ring chronologies at several sites, following a similar pattern to the results obtained when using the regional average (Fig. $5 \mathrm{~A})$, but a larger number of months are involved in this relationship (Fig. 6A). Thus, tree-ring chronologies are positively correlated with a range of months that includes the spring-autumn months (September-May) of the current growing season, whereas for the previous growing season the range of months extends to the summer in some cases (January-March, Fig. 6A). Punta Arenas precipitation record shows a negative correlation with PCH, NAS, NBA, NBK, NVA and NVK, but also has a positive correlation with AGA and TEF, the driest study sites located in the ecotone with the Patagonic steppe. AGA shows a positive significant correlation with September and November precipitation of the current growing season, and February of the previous growing season. TEF has a similar pattern with February precipitation of the current growing season, and also with February of the previous growing season. Site NBA also shows positive correlation with December-January precipitation of the current growing season (Fig. 6B). These positive correlations with precipitation may be explained by the environmental gradient throughout the region with drier sites towards the east or north-east (Fig. 1 and $6 \mathrm{~B})$.

\section{Reconstruction of temperature (1829-1996)}

Based on the tree-ring response to climatic variations, and after trying diverse combinations of 
A

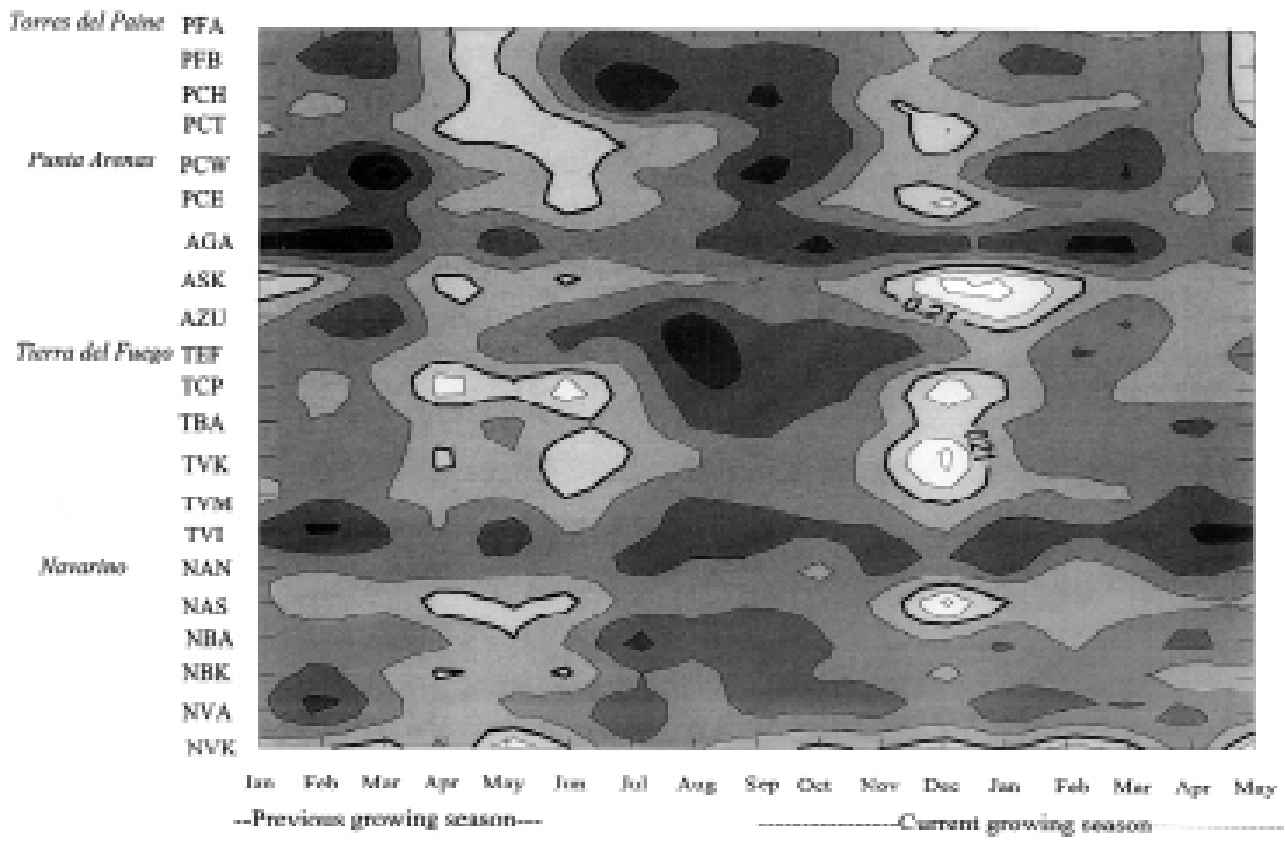

B

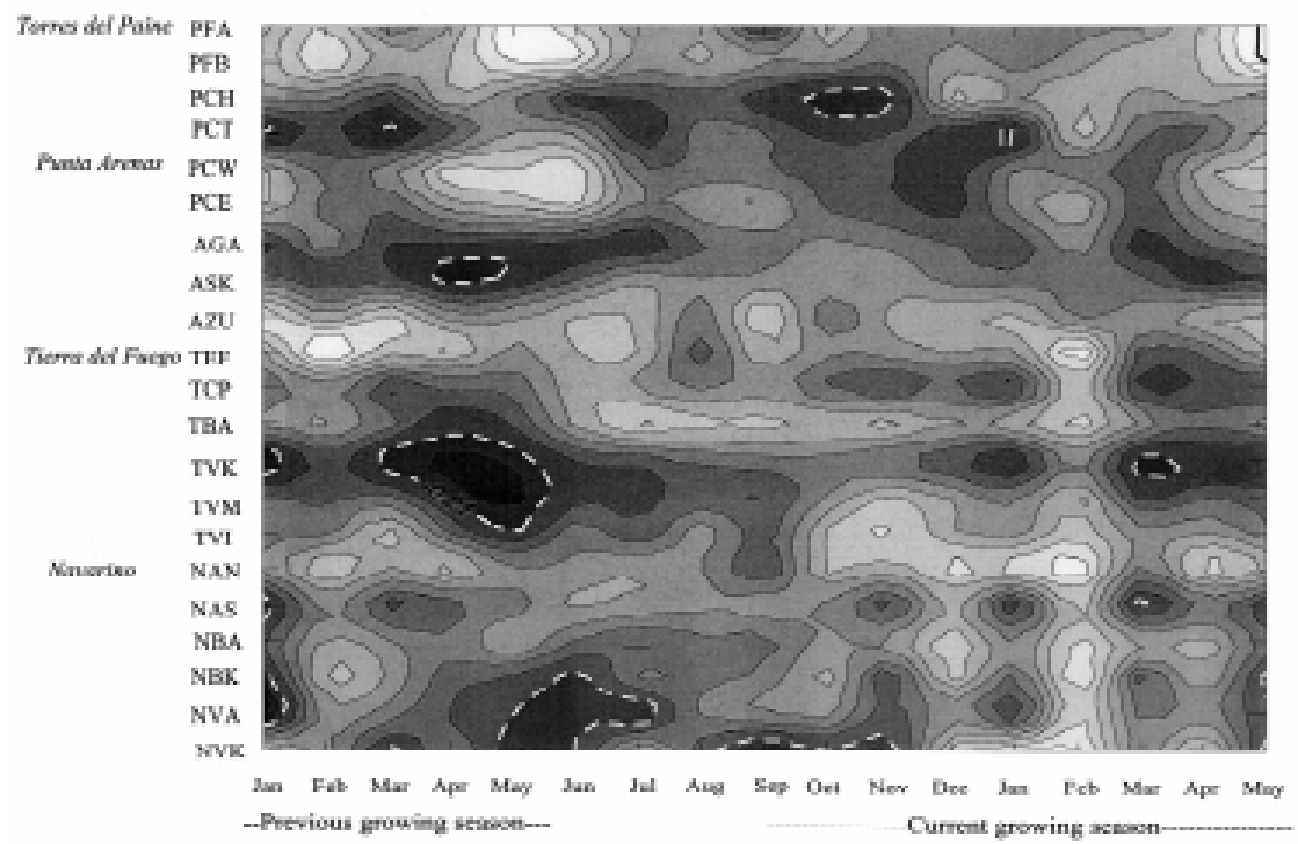

Month

Fig. 5: Spatial and time distribution of correlation between regional month averages for temperature (A) and precipitation (B), and tree-ring indices of 21 Nothofagus pumilio standard chronologies of southern Chilean Patagonia. Statistically significant correlations are indicated as areas enclosed by the $95 \%$ of confidence isoline (in our case Pearson correlation $\geq \pm 0.21$ ). See Table 1 for the identification of the study sites.

Distribución espacial y temporal de la correlación entre los promedios regionales mensuales de temperatura (A) y precipitación (B), y los índices de crecimiento de las 21 cronologías estándar de Nothofagus pumilio de la Patagonia austral de Chile. Las correlaciones estadísticamente significativas se indican como las áreas encerradas por la isolínea de un $95 \%$ de confianza (en nuestro caso correlación de Pearson $\geq \pm 0,21$ ). Ver Tabla 1 para la identificación de los sitios de estudio. 


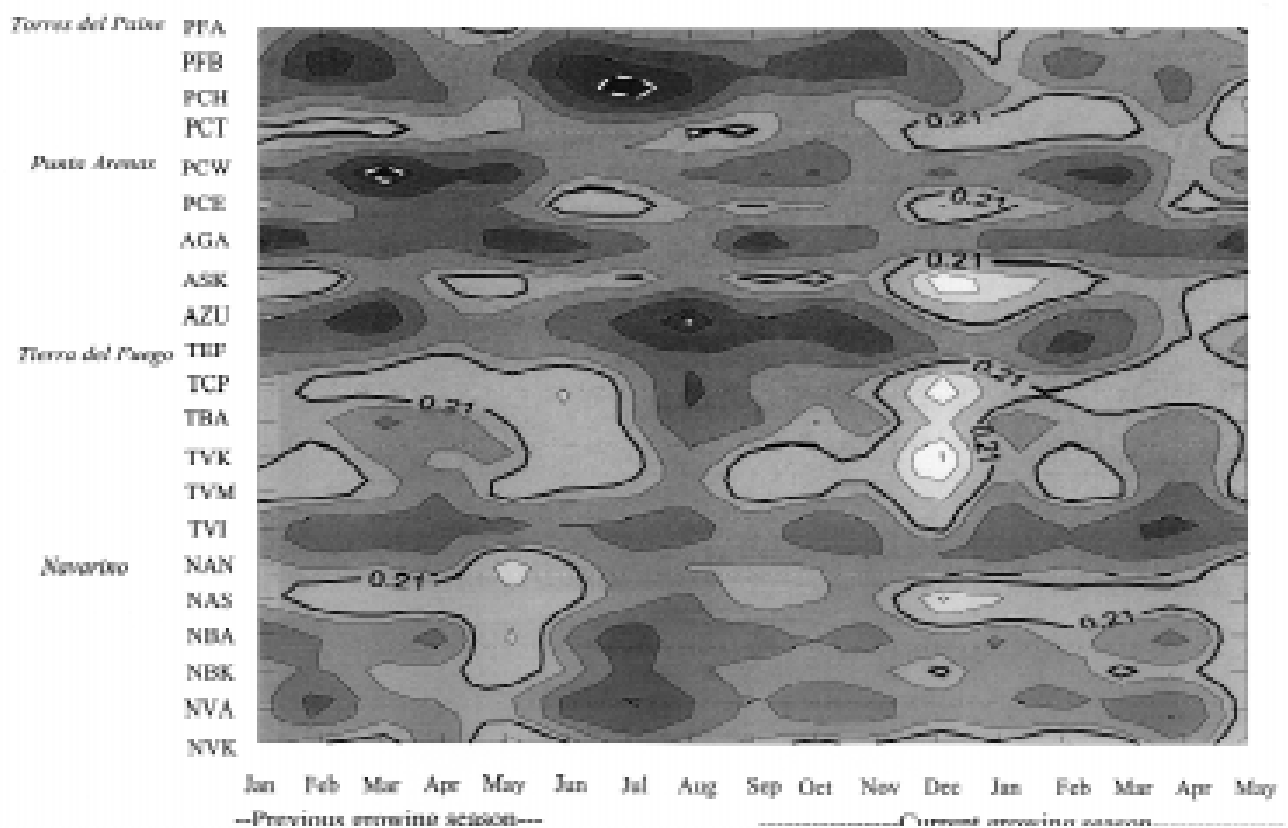

B

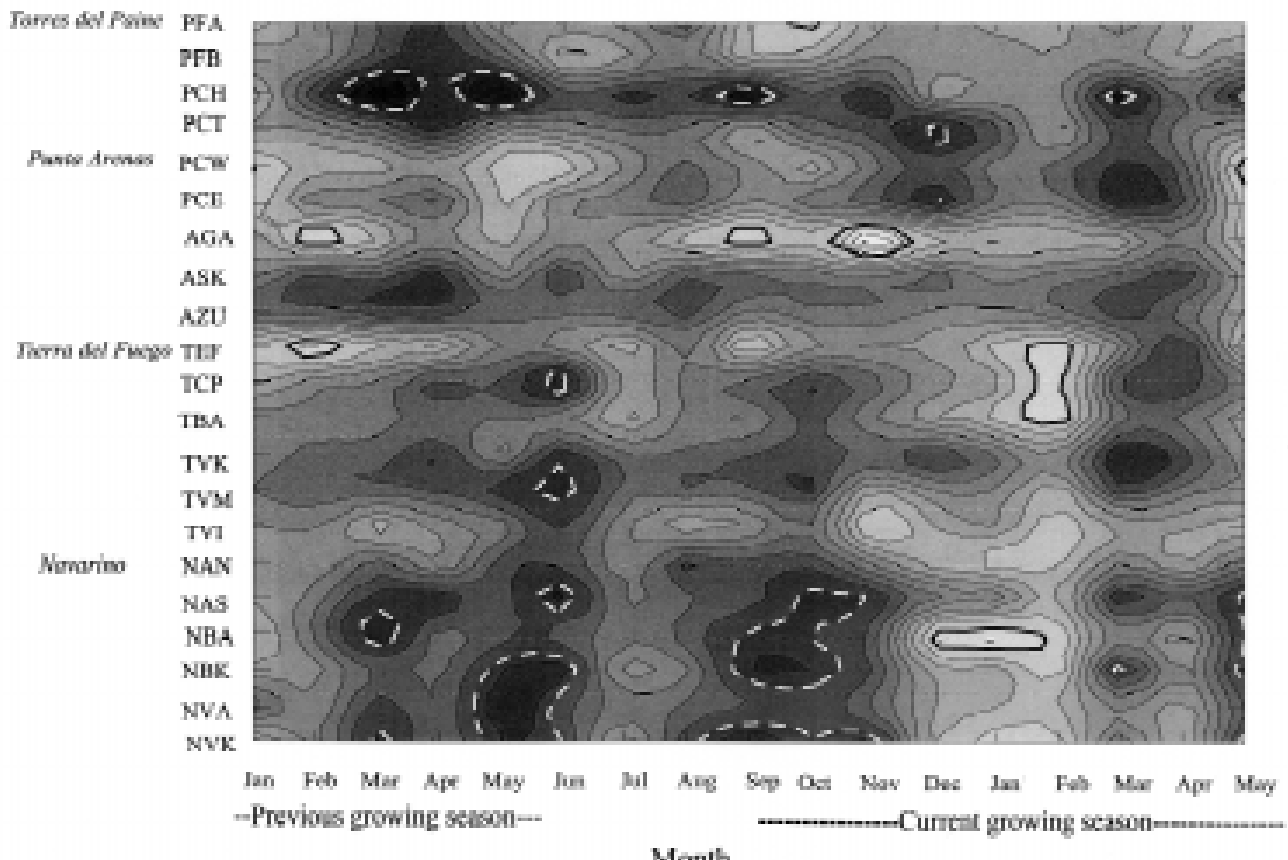

Fig. 6: Spatial and time distribution of correlation between Punta Arenas climatic station records for temperature (A) and precipitation (B), and tree-ring indices of 21 Nothofagus pumilio standard chronologies of Southern Chilean Patagonia. Statistically significant correlations are indicated as areas enclosed by the $95 \%$ of confidence isoline (in our case Pearson correlation $\geq \pm 0.21$ ). Positive correlations are shown by a continuous line, and negative correlations are shown by a dashed line. See Table 1 for the identification of the study sites.

Distribución espacial y temporal de la correlación entre los registros de la estación climática de Punta Arenas para temperatura (A) y precipitación (B), y los índices de crecimiento de las 21 cronologías estándar de Nothofagus pumilio de la Patagonia austral de Chile. Las correlaciones estadísticamente significativas se indican como las áreas encerradas por la isolínea de un $95 \%$ de confianza (en nuestro caso correlación de Pearson $\geq \pm 0,21$ ). Las correlaciones positivas se indican con una línea contínua y las negativas con una línea segmentada. Ver Tabla 1 para la identificación de los sitios de estudio. 
TABLE 4

Calibration and verification statistics computed for the tree-ring based reconstruction of minimum mean annual temperature for Punta Arenas

Estadísticas de calibración y verificación para la reconstrucción basada en anillos de crecimiento de la temperatura minima promedio anual para Punta Arenas

\begin{tabular}{cccccc}
\hline \multicolumn{2}{c}{ Calibration } & \multicolumn{2}{c}{ Verification } \\
Time period & $\mathrm{r}^{2}$ adj a & Time period & $\mathrm{r}^{\mathrm{b}}$ & $\mathrm{t}^{\mathrm{c}}$ & $\mathrm{RE}^{\mathrm{d}}$ \\
\hline $1931-1961$ & 0.31 & $1962-1992$ & 0.57 & 6.88 & +0.69 \\
$1962-1992$ & 0.30 & $1931-1961$ & 0.58 & 5.45 & +0.72 \\
$1931-1992$ & 0.50 & & & & \\
\hline
\end{tabular}

${ }^{a}$ the square of the multiple correlation coefficient adjusted for loss of degree of freedom

${ }^{b}$ Pearson correlation coefficient

${ }^{\mathrm{c}}$ The product mean test (Fritts 1976)

${ }^{\mathrm{d}}$ Reduction error statistic (Fritts 1976)

temperature, precipitation and tree-ring data sets, we selected the Punta Arenas climatic station as the most suitable climatic series to be reconstructed from southern Chilean Patagonia treerings. In particular, we found that Punta Arenas mean annual minimum temperature is the climatic variable most highly correlated with Nothofagus pumilio tree growth in southern Patagonia. We used multiple regression on principal components (Cooley \& Lohnes 1971) to predict mean annual minimum temperature as a function of tree-ring growth. Following this procedure, seven variables were selected to be included in the principal component analysis: chronologies PCT, PCE, ASK, TCP, TVK, TVM and NAS, all in year $t$. The rest of the chronologies were excluded from this analysis because they were not significantly (at the $5 \%$ level) correlated with the 1930-1992 temperature record. In addition, all the Isla Navarino chronologies, except NAS, and some chronologies of Tierra del Fuego study area, were excluded as a way to prevent the effect of the 7-year cycle growth pattern on the climate reconstruction (Fig. 3 and 4 ). The first principal component (PC1) accounted for $53 \%$ of the total variance in temperature derived from an un-rotated PCA of the seven selected variables. Therefore, PC1 was selected in the regression procedure. The loadings of the selected chronologies contribute to the first PC with values over 0.5 , indicating the strong correlation of these variables with temperature.

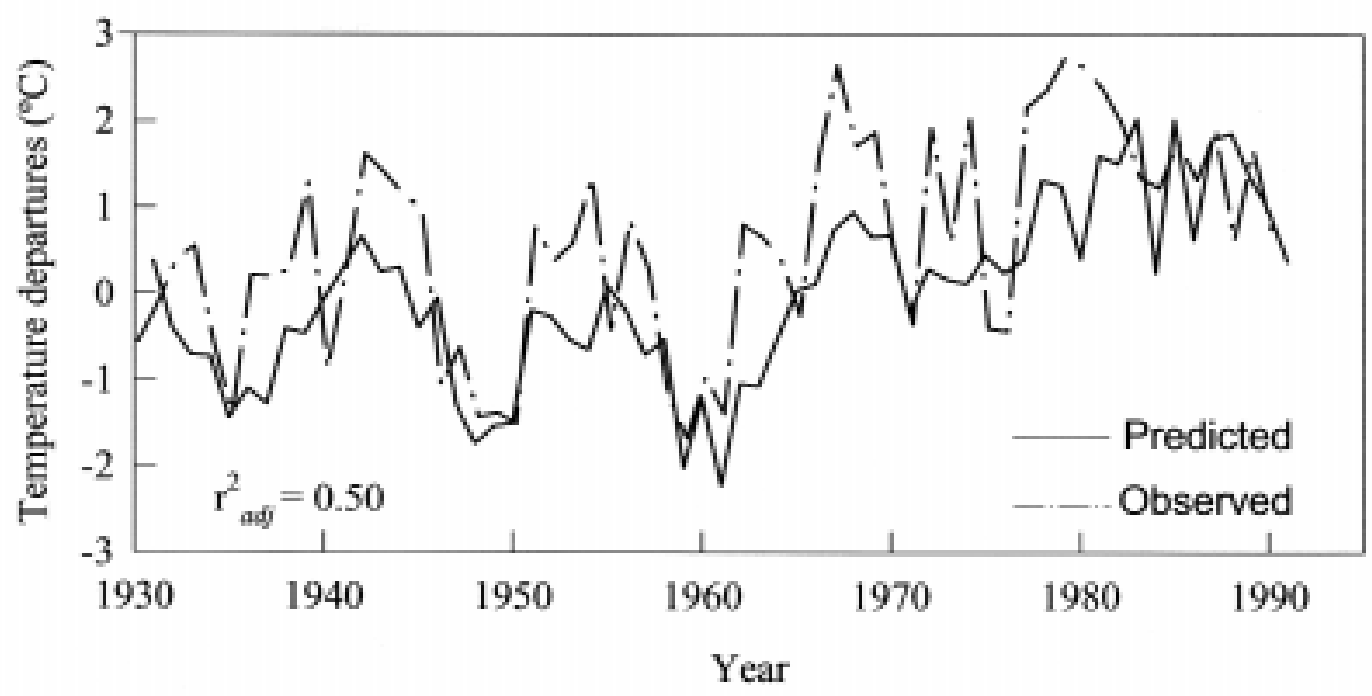

Fig. 7: Observed and predicted minimum annual temperature variations for Punta Arenas from 1931 to 1992.

Variaciones de la temperatura mínima anual observadas y predichas para Punta Arenas desde 1931 a 1992. 
The statistics of calibration and verification show significant values, indicating a good predictive skill in the regression models (Table 4). The verification statistics are similarly strong for the most recent period (1962-1992) as for the early portion (1931-1961) of the minimum annual temperature record used for the reconstruction. In general, the predicted temperature reconstruction captures both high- and low-frequency variations in the observed instrumental record, with a better ability to predict the observed below-average temperatures that are limiting tree growth (Fig. 7).

We used the whole 1930-1992 period to develop the final regression equation for reconstructing minimum annual temperature, obtaining an adjusted $\mathrm{r}^{2}$ of 0.50 (Table 4). Using this regression model, we produced a mean annual minimum temperature reconstruction back to 1829 , the year where all the predictor chronologies used in the reconstruction had at least five series (Fig. 8 ). The reconstruction shows that during most of the $19^{\text {th }}$ century, minimum annual temperatures remained below-average and increased to values fluctuating around the mean during the period 1900-1960, followed by a clear trend with aboveaverage values after 1963 (Fig 8).

\section{DISCUSSION}

The southern Chilean Patagonia region shows marked climatic gradients regarding latitude, elevation and position along a west-east axis, (shifting to south-west to north-east further south). In order to include most of the climatic variability of the region, the sampling sites were located along these gradients trying to capture this variability in the Nothofagus pumilio tree line growth trends. Therefore, the differences between tree growth responses to the climatic fluctuations observed among study sites reflect differences in the position and location of each sampling site along these gradients. In the northernmost areas of Torres del Paine, drier sites located towards the east (PCT and PCE) show the most evident increase in growth after ca. 1960. In Punta Arenas, ASK shows a steep increase after 1978 that might be associated to a local disturbance. Further south, in Tierra del Fuego and Isla Navarino, sites located at higher elevations also show aboveaverage growth since ca. 1960 (sites TVK, TCP and TBA).

Tree-growth of Nothofagus pumilio forests at the upper treeline in the southern Chilean Patagonia shows a positive correlation with temperature, supporting one of our initial hypotheses, making it a very good proxy record for temperature fluctuations during the last 200 years in this region. This positive correlation has also been shown in the Nothofagus pumilio forests of the Argentinean Tierra del Fuego and Isla de los Estados (Boninsegna et al. 1989), and northern Patagonia at $41^{\circ} \mathrm{S}$ (Villalba et al. 1997). A different and contrasting pattern was found in the northernmost portion of the Nothofagus pumilio geographic range in Chile $\left(35^{\circ} 36^{\prime}-37^{\circ} 30^{\prime} \mathrm{S}\right)$ where radial growth is positively correlated with late-spring and early-summer precipitation, and negatively correlated with temperature (Lara et al. 2001). High temperatures in spring and sum-

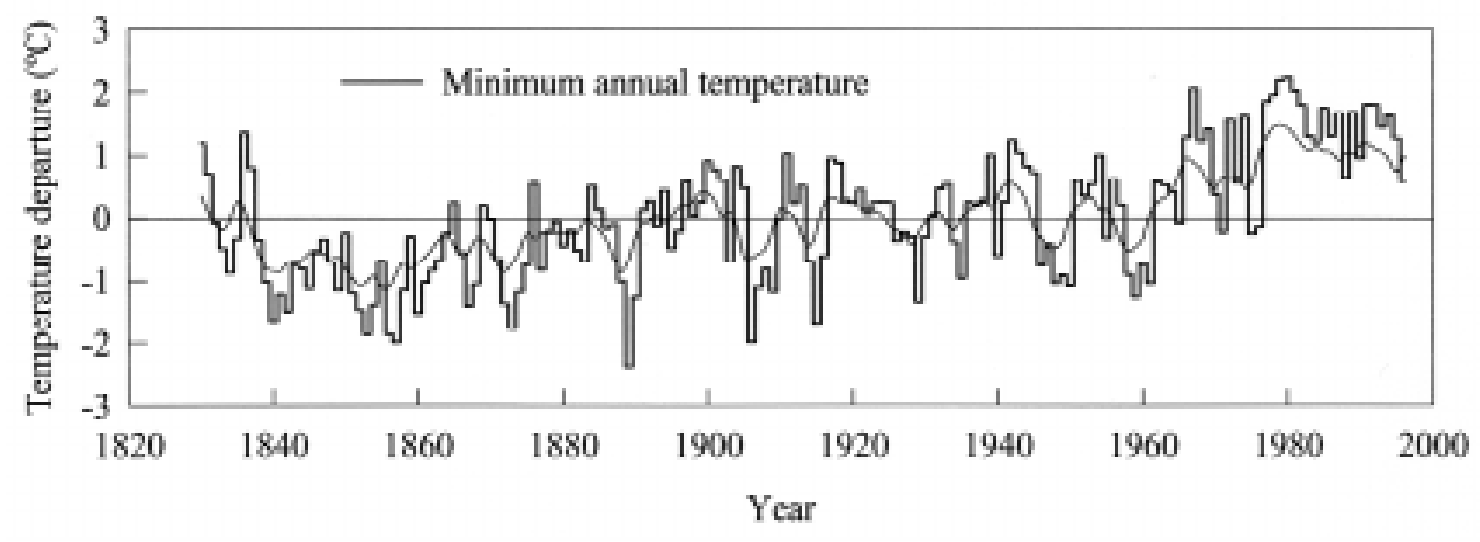

Fig. 8: Tree-ring based reconstruction of minimum annual temperature for Punta Arenas from 1829 to 1996. A trend line drawn to emphasize the low-frequency variation was obtained using an exponential filter (Rosenblüth et al. 1997).

Reconstrucción de la temperatura mínima anual, basada en anillos de crecimiento arbóreo, para Punta Arenas desde 1829 a 1996. La línea de tendencia dibujada enfatiza la variación de baja frecuencia y se obtuvo usando un filtro exponencial (Rosenblüth et al. 1997). 
mer, which enhance evapotranspiration and decrease water availability, appear to reduce treegrowth at these northern sites, characterized by Mediterranean-type climate with very low precipitation during the growing season (Lara et al. 2001).

In addition to the tree-growth response to temperature, we found a negative correlation between a few chronologies and precipitation records in southern Chilean Patagonia. These results could be indicating a negative influence on tree growth of more extended snowfall seasons associated to higher precipitation years, as those described for Northern Patagonia in Argentina at $41^{\circ} \mathrm{S}$. (Villalba et al. 1997). Conversely, the chronologies of sites AGA and TEF, located right at the ecotone with the Patagonian steppe have a positive correlation with precipitation, validating our hypothesis of a precipitation signal in the tree-ring records at the easternmost driest sites in the region (Fig. 1 and 6B).

The significant correlation between $N$. pumilio growth and temperature allowed us to reconstruct minimum annual temperature fluctuations since 1829. This reconstruction shows an important warming trend since 1963 , coinciding with the patterns seen in the instrumental records (Fig. 7 and 8 ). These results confirm our initial hypothesis regarding increased tree-growth during the recent decades as a response to increased temperatures. This warming trend in the recent decades coincides with the pattern described for the extreme south of South America $\left(45-55^{\circ} \mathrm{S}\right)$, which is not present in the area north of this region (40-43 $\mathrm{S}$, Rosenblüth et al. 1997).

These results show a general trend in the response of Nothofagus pumilio growth to climate along its geographic range. However, our results also demonstrate that the response to climate is strongly influenced by local site factors, given that the positive correlation with temperature was significant only in seven out of 21 tree-ring. The same conclusion has been pointed out for northern Patagonia in Argentina $\left(41^{\circ} \mathrm{S}\right)$ by Villalba et al. (1997) and by Schmelter (2000) analyzing the climatic responses of Nothofagus pumilio forests along elevation and west to east gradients.

An additional growth-pattern that we found was the marked 7-year persistent cyclic growth pattern observed in several study sites in Isla Navarino (NAN, NBA and NVK). This pattern is one of the most outstanding characteristics of tree-growth variability of this region and concentrates the larger portion of the variance of the spatial variability and inter-correlation among tree-ring chronologies of southern Chilean Patagonia. This 7-year cycle has been reported by Boninsegna et al. (1989), and Roig et al. (1996), also associated to Nothofagus pumilio forests and local conditions. This cyclic pattern in growth does not appear to be associated with climatic variations. The presence of the 7-year cycle in the southernmost area and within certain sites leads to the idea that it could be associated with local site conditions or biological interactions not yet clearly explained. Episodic insect outbreaks of Ormiscodes spp. defoliators and Chilecomadia spp. borers have been reported for $N$. pumilio forests in Northern Argentinean Patagonia (Veblen et al. 1996). Also insects belonging to the Geometrids family would be responsible of the defoliation of $N$. pumilio in the area of Punta Arenas (Veblen et al. 1996).

Interestingly, a cycle of 7-9 years in radial growth has been reported for larch (Larix decidua) in the Alps, due to periodic outbreaks of the grey larch bud moth (Zeiraphera diniana G.N.) (Schweingruber 1996). Nevertheless, the causes of the 7-year cycle found by us and other authors in the Nothofagus pumilio tree-ring records in Patagonia, remain unknown and need to be further investigated.

\section{ACKNOWLEDGMENTS}

We thank Corporación Nacional Forestal (CONAF) for the necessary permits to develop this investigation in Torres del Paine National Park. We are also thankful to Sebastián Díaz, Darby Jack, Montserrat and Gabriel Lara, for their valuable help in the collection of samples in the field. We also acknowledge the cooperation of Maurice Van der Maalen, Director of the Museo Antropológico of Puerto Williams, for his help in the area of Isla Navarino. This work was funded by FONDECYT (Chilean National Science Fund, grant 1970812), and by the Institute of Global Change (IAI), grant CRN 03.

\section{LITERATURE CITED}

BLASING TJ, AM SOLOMON \& DN DUVICK (1984) Response function revisited. Tree-Ring Bulletin 44: $1-15$.

BONINSEGNA JA, J KEEGAN, GC JACOBY, R D'ARRIGO \& RL HOLMES (1989) Dendrochronological studies in Tierra del Fuego, Argentina. Quaternary of South America and Antarctic Peninsula 7: 305-326.

CARRASCO JF, G CASASSA \& A RIVERA (1998) Climatología actual del Campo de Hielo Sur y posibles cambios por el incremento del efecto invernadero. Anales del Instituto de la Patagonia, Serie Ciencias Naturales (Chile) 26: 119-128. 
COOLEY WW \& PR LOHNES (1971) Multivariate data analysis. Wiley \& Sons, New York, New York. 364 pp.

COOK E (1985) A time series analysis approach to treering standardization. Ph.D. Dissertation, University of Arizona, Tucson, Arizona. 171 pp.

COOK E \& RL HOLMES (1984) Program ARSTAN user manual. Laboratory of Tree-Ring Research, University of Arizona, Tucson, Arizona. 36 pp.

COOK E, T BIRD, M PETERSON, M BARBETTI, B BUCKLEY, R D'ARRIGO \& R FRANCEY (1992) Climatic change over the last millennium in Tasmania reconstructed from tree-rings. The Holocene 2: 205-217.

CUEVAS JG \& MTK ARROYO (1999) Ausencia de banco de semilla persistente en Nothofagus pumilio (Fagaceae) en Tierra del Fuego, Chile. Revista Chilena de Historia Natural 72: 73-82.

DONOSO C (1981) Tipos forestales de los bosques nativos de Chile. Corporación Nacional Forestal y FAO, Documento de Trabajo 38: 1-70.

DONOSO C (1993) Bosques templados de Chile y Argentina. Editorial Universitaria, Santiago Chile. 484 pp.

FRITTS HC (1976) Tree rings and climate. Academic Press, London, United Kingdom. 567 pp.

FRITTS HC (1991) Reconstructing large-scale climatic patterns from tree-ring data. The University of Arizona Press, Tucson, Arizona. 286 pp.

GODLEY EJ (1960) The botany of southern Chile in relation to New Zealand and the subantarctic. Proceedings of the Royal Society of London B 152: 457475.

HOLMES RL (1983) Computer-assisted quality control in tree-ring dating and measurement. Tree Ring Bulletin 43: 69-75.

JENKINS GM \& DG WATTS (1968) Spectral analysis and its applications. Holden-Day, San Francisco, California. $170 \mathrm{pp}$.

KING JC (1984) Recent climate variability in the vicinity of the Antarctic Peninsula. International Journal of Climatology 14: 357-369.

LARA A, JC ARAVENA, R VILLALBA, A WOLODARSKY-FRANKE, BH LUCKMAN \& R WILSON (2001) Dendroclimatology of high-elevation Nothofagus pumilio forests at their northern distribution limit in the central Andes of Chile. Canadian Journal of Forest Research 31: 925-936.

PAYETTE S \& L FILION (1984) White spruce expansion at the tree line and recent climatic change. Canadian Journal of Forestry Research 15: 241-251.
PISANO E (1977) Fitogeografía de Fuego-Patagonia chilena. I: Comunidades vegetales entre las latitudes $52^{\circ}$ y $56^{\circ} \mathrm{S}$. Anales del Instituto de la Patagonia (Chile) 8: 121-250.

ROBINSON EJ \& R EVANS (1980) A microcomputerbased tree-ring measuring system. Tree-Ring Bulletin 40: 59-64.

ROIG F Jr, C ROIG, J RABASSA \& J BONINSEGNA (1996) Fuegian floating tree-ring chronology from subfossil Nothofagus wood. The Holocene 6: 469476.

ROSENBLÜTH B, H FUENZALIDA \& P ACEITUNO (1997) Recent temperature variations in southern South America. International Journal of Climatology 17: 67-85.

SCHMELTER A (2000) Climatic response and growthtrends of Nothofagus pumilio along altitudinal gradients from arid to humid sites in northern PatagoniaA progress report. In: Roig FA (ed) Dendrocronología en América Latina: 193-215. Editorial de la Universidad Nacional de Cuyo, Mendoza, Argentina.

SCHULMAN E (1956) Dendroclimatic change in semiarid America. University of Arizona Press, Tucson, Arizona. $142 \mathrm{pp}$.

SCHWEINGRUBER FH (1996) Tree rings and environment. Dendroecology. Birmensdorf, Swiss Federal Institute for Forest, Snow and Landscape Research. Berne, Switzerland. 609 pp.

STOKES MA \& TL SMILEY (1968) An introduction to tree-ring dating. University of Chicago Press, Chicago, Illinois. $73 \mathrm{pp}$.

VEBLEN TT \& FM SCHLEGEL (1982) Reseña ecológica de los bosques del sur de Chile. Bosque (Chile) 2: 73 115 .

VEBLEN TT, FM SCHLEGEL \& JV OLTREMARI (1983) Temperate broad-leaved evergreen forests of South America. In: Ovington JD (ed) Temperate broadleaved evergreen forests: 5-31. Elsevier Science Publishers, Amsterdam, The Netherlands.

VEBLEN TT, T KITZBERGER, BR BURNS \& AJ ROBERTUS (1996) Perturbaciones y dinámica de regeneración en bosques andinos del sur de Chile y Argentina. In: Armesto J, C Villagrán \& M Kalin (eds) Ecología de los bosques nativos de Chile: 169198. Editorial Universitaria, Santiago, Chile.

VILLALBA R, JA BONINSEGNA, TT VEBLEN, A SCHMELTER \& S RUBULIS (1997) Recent trends in tree-ring records from high elevation sites in the Andes of northern Patagonia. Climatic Change 36: 425-454. 